\title{
Capnocytophaga gingivalis aminopeptidase: a potential virulence factor
}

\author{
D. A. Spratt, J. Greenman and A. G. Schaffer \\ Author for correspondence: J. Greenman. Tel: +44117976 3836. Fax: +44 1179763871.
}

Department of Biological Sciences, Faculty of Applied Sciences, The University of the West of England, Bristol, Frenchay Campus, Coldharbour Lane, Bristol BS16 1QY, UK

\begin{abstract}
The production and properties of an aminopeptidase from Capnocytophaga gingivalis were studied. $\mathbf{C}$. gingivalis was grown in continuous culture over a range of dilution rates and the cell-bound and extracellular levels of aminopeptidase and trypsin-like protease (TLPase) measured. At high growth rates $\left(0.6 \mu_{\text {rot }}\right)$ TLPase specific activity was low and found exclusively as cellbound activity; at low growth rates $\left(0.0375 \mu_{\text {reil }}\right)$, specific activity was high and $\mathbf{2 6} \%$ was found as extracellular activity. In contrast, aminopeptidase specific activity was highest at $0.3 \mu_{\mathrm{rol}}$ and the ratio of cell-bound to extracellular activity was relatively constant at all growth rates. Only about $5 \%$ of the total activity was extracellular. The aminopeptidase, which has a wide specificity towards artificial substrates, was purified to homogeneity, as judged by SDSPAGE, from the supernatant fluid of cells grown in continuous culture in a tryptone/glucose/thiamine medium. The enzyme has a molecular mass of $61 \mathrm{kDa}$, a pl of 6.3, a pH optimum close to 7.5 and showed a requirement for magnesium or calcium ions. The $\mathrm{N}$-terminal sequence of the first 10 amino acids (Asp-Val-Asn-Met-Leu-Trp-Tyr-Val-x-Arg...) showed no similarity to any published sequence. This enzyme in its cell-bound or extracellular form may be important in the nutrition and pathogenesis of $C$. gingivalis in the human oral cavity.
\end{abstract}

Keywords: Capnocytophaga gingivalis, oral cavity, aminopeptidase, trypsin-like protease, extracellular and cell-bound enzymes

\section{INTRODUCTION}

The genus designation of Capnocytophaga was conferred by Leadbetter et al. (1979) who characterized some nonflagellated, gliding, Gram-negative fusiform bacteria isolated from the human oral cavity. C. gingivalis is thought to form part of the normal oral flora (Holdeman et al., 1985), and is present in both supragingival and subgingival plaque. Members of the genus have been implicated in juvenile periodontal disease (Newman et al., 1976; Slots, 1976) and periodontal disease associated with insulindependent diabetes mellitus (Mashimo et al., 1983). In mono-infected rats, Capnocytophaga spp. cause periodontal disease between the first and second maxillary molars, with accompanying migration of the gingival margin and destruction of alveolar bone (Irving et al., 1978). Their

Abbreviations: BAPNA, $N$ - $\alpha$-benzoyl-L-arginine-p-nitroanilide; TLPase, trypsin-like protease.

The EMBL accession number for the $\mathrm{N}$-terminal amino acid sequence data reported in this paper is $\mathbf{P 8 0 4 7 4 .}$ pathogenic potential has been attributed in part to the production of tissue-destroying hydrolytic enzymes (Nakamura \& Slots, 1982; Shibata et al., 1992). In addition to aminopeptidase activity, a trypsin-like protease has been identified, purified and characterized (Shibata $e t$ al., 1992). However the biochemical basis of the pathogenicity of these organisms has yet to be determined.

The aminopeptidase of Capnocytophaga may be an important virulence factor in associated pathological conditions owing to its postulated involvement in bradykinin formation (Hopsu-Havu et al., 1966) and degradation of collagen fragments (Ando, 1980; Nakamura \& Slots, 1982). Aminopeptidases of both bacterial and fungal origin have been implicated in the mechanism of pathogenesis by reason of association (Green et al., 1967; D'Amato et al., 1978), but there is little information on aminopeptidase production by Capnocytophaga gingivalis.

As part of our studies on the physiology and biochemistry of the oral flora, we decided to define optimum conditions for production and activity of the aminopeptidase of $C$. 
gingivalis. Continuous culture using chemostats has been used to study the physiology of periodontal microorganisms by various workers (Greenman et al., 1981; Marsh et al., 1983). Here we also describe the properties of the purified enzyme, including the molecular mass, specificity towards artificial chromogenic substrates, cation requirement and $\mathrm{N}$-terminal amino acid sequence analysis. This work may provide a basis for further investigations of the pathogenicity of $C$. gingivalis, since purified enzyme and $\mathrm{N}$-terminal sequence data can be used for the production of specific antibodies and oligonucleotide probes, respectively.

\section{METHODS}

Organisms and culture maintenance. Capnocytophaga gingivalis strain ATCC 33624 was obtained from the American Type Culture Collection Rockville, MD, USA. This Gram-negative fusiform bacterium requires a $\mathrm{CO}_{2}$-enhanced $(>5 \%)$ atmosphere for growth. Cultures were maintained on fastidious anaerobe agar (FAA) supplemented with horse blood $(5 \%$ $\mathrm{v} / \mathrm{v})$. Plates were incubated in an anaerobic cabinet at $37^{\circ} \mathrm{C}$, in an atmosphere of $\mathrm{N}_{2} / \mathrm{H}_{2} / \mathrm{CO}_{2}(80: 10: 10$ by vol.). Cultures were stored at $-70^{\circ} \mathrm{C}$ on porous beads (Microbank).

Continuous culture. $C$. gingivalis was grown in a chemostat vessel ( $1 \mathrm{l}$ ) with control modules for temperature, $\mathrm{pH}$ and stirrer rate (LH Fermentation). The culture volume $(750 \mathrm{ml})$ was maintained at $37^{\circ} \mathrm{C}\left( \pm 0.1{ }^{\circ} \mathrm{C}\right)$, and the $\mathrm{pH}$ at 7.0 ( \pm 0.05 units) by automatic addition of $2 \mathrm{M} \mathrm{NaOH}$ or $1 \mathrm{M} \mathrm{H}_{2} \mathrm{SO}_{4}$. The impeller speed was 500 r.p.m. ( \pm 10 r.p.m.). The vessel was sparged with $\mathrm{N}_{2} / \mathrm{CO}_{2}$ and air to give an $\mathrm{N}_{2} / \mathrm{O}_{2} / \mathrm{CO}_{2}$ ratio of 85:10:5 (by vol.). The growth media consisted of brain heart infusion (18.5 $\left.\mathrm{g} \mathrm{l}^{-1}\right)$ and yeast extract $\left(5 \mathrm{~g} \mathrm{l}^{-1}\right)$ for growth rate studies, and tryptone $\left(18.5 \mathrm{~g} \mathrm{l}^{-1}\right)$, glucose $\left(2 \mathrm{~g} \mathrm{l}^{-1}\right)$ and thiamine $\left(0.5 \mathrm{mg} \mathrm{l}^{-1}\right)$ for the production of aminopeptidase for purification. The maximum specific growth rate $\left(\mu_{\max }\right)$ was determined by the washout method (Tempest, 1970) and a dilution rate was set to give the required growth rate. To study the effect of dilution rate on aminopeptidase and trypsin-like protease (TLPase) production, the medium addition pump was adjusted to give a range of growth rates between 0.0375 and $0.6 \mu_{\text {rel }}$. At each dilution rate, once steady state was achieved, standard assays were carried out for aminopeptidase and TLPase. Assays were carried out, in quadruplicate, on three consecutive samples taken from steady-state culture over a $3 \mathrm{~d}$ period and means of the 12 determinations calculated.

Enzyme assays. Assays for aminopeptidase and TLPase were measured using the chromogenic substrates, L-leucine- $p$ nitroanilide and $N$ - $\alpha$-benzoyl-L-arginine- $p$-nitroanilide (BAPNA), respectively, which upon hydrolysis produce the coloured end-product, $p$-nitroaniline $\left(\lambda_{\max }=410 \mathrm{~nm}\right)$. Both assays were carried out in a total volume of $300 \mu$ in the wells of a microtitre plate. The aminopeptidase assay mixture consisted of $230 \mu \mathrm{l}$ MOPS buffer $(0.1 \mathrm{M}, \mathrm{pH} 7.5)$ and $50 \mu \mathrm{l}$ leucine- $p$ nitroanilide substrate $(8 \mathrm{mM})$. A $20 \mu \mathrm{l}$ aliquot of enzyme preparation or cell suspension was added to the well and the contents mixed to start the reaction. The TLPase assay consisted of $180 \mu \mathrm{l}$ MOPS buffer $(0 \cdot 1 \mathrm{M}, \mathrm{pH} 7 \cdot 5), 100 \mu \mathrm{l}$ BAPNA $(0.2 \mathrm{mM})$ and $20 \mu \mathrm{l}$ enzyme. The absorbance change was followed using a microtitre plate reader (Anthos ht II) at a wavelength of $410 \mathrm{~nm}$, taking absorbance readings at $1 \mathrm{~min}$ intervals for $10 \mathrm{~min}$ and calculating the rate of reaction. All assays were conducted at room temperature $\left(19 \pm 2{ }^{\circ} \mathrm{C}\right)$.

Assays were carried out using culture supernatant with a range of $0.1 \mathrm{M}$ zwitterionic buffers to determine the $\mathrm{pH}$ optimum for catalytic activity for both enzymes. The buffers used were: MES (pH 5.5-6.7), MOPS (pH 6.5-7.9), HEPES (pH 6.8-8.2), Bicine $(\mathrm{pH} 7 \cdot 6-9 \cdot 0)$, CHES (pH 8.9-10.0) and CAPS ( $\mathrm{pH} 9 \cdot 7-11 \cdot 1)$. The $\mathrm{pH}$ of each assay mixture was checked before and after incubation to ensure that no $\mathrm{pH}$ change had occurred $\left(19 \pm 2{ }^{\circ} \mathrm{C}\right)$. The optimum assay $\mathrm{pH}$ for both enzymes was used for all subsequent assays.

Units of enzyme activity. A unit of activity is defined as $\mu \mathrm{mol}$ product formed (under the conditions of the assay) $\mathrm{min}^{-1}$. Specific activity is defined as enzyme units ( $\mathrm{mg}$ dry wt of bacterial cells $)^{-1}$. Specific activity in the supernatant fraction was related to the dry weight of cells in the culture sample before centrifugation. During purification procedures, specific activity is defined as enzyme units ( $\mathrm{mg}$ protein $)^{-1}$. The quantity of product formed was calculated using the molar extinction coefficient $(\varepsilon)$ of $p$-nitroaniline at $410 \mathrm{~nm}\left(10000 \mathrm{M}^{-1} \mathrm{~cm}^{-1}\right)$. Dry weights were determined by the method of Holland et al. (1979) and culture absorbances were related to dry weight with reference to a calibration curve.

Purification of the aminopeptidase. Large samples $(500 \mathrm{ml})$ of the culture grown in tryptone/glucose/thiamine medium, from the chemostat (grown at $0.3 \mu_{\text {rel }}$ ), were centrifuged for $20 \mathrm{~min}$ at $5000 \mathrm{~g}$ (Beckman $\mathrm{J} 2-21$ ) at $4^{\circ} \mathrm{C}$. The supernatant was concentrated by ultrafiltration at $4{ }^{\circ} \mathrm{C}$ using a $10 \mathrm{kDa}$ filter (PM 10 , $76 \mathrm{~mm}$ diameter) with a pressure of $2.4 \times 10^{5}$ Pa provided by $\mathrm{N}_{2}$ gas. The concentrate was termed crude enzyme preparation. Protein content was estimated by the Coomassie blue method for all samples (Bradford, 1976).

The crude enzyme preparation was dialysed against $20 \mathrm{mM}$ Tris/ $\mathrm{HCl}$ buffer $(\mathrm{pH} 8.0)$ overnight at $4{ }^{\circ} \mathrm{C}$, filtered through a $0.2 \mu \mathrm{m}$ filter (Acrodisk, Gelman Sciences) and applied to an ion exchange column (Mono Q HR 5/5) equilibrated with $20 \mathrm{mM}$ Tris/ $\mathrm{HCl}(\mathrm{pH} \mathrm{8.0)}$. The proteins were eluted from the column with a linear gradient of $0.4-0.6 \mathrm{M} \mathrm{NaCl}$ in equilibration buffer. Fractions $(0.5 \mathrm{ml})$ were collected and assayed for aminopeptidase activity. Fractions showing significant activity were pooled and concentrated by filtration (Cetricon-10 concentrators, Amicon) at $5000 \mathrm{~g}$. The concentrated fractions from the ion exchange step were applied to a gel filtration column (Superose $1210 / 30$ ) equilibrated with buffer $(50 \mathrm{mM}$ Tris, $100 \mathrm{mM} \mathrm{NaCl}, \mathrm{pH} 7 \cdot 4)$ or buffer and Triton X-100 (0.5\% v/v). Fractions $(0.5 \mathrm{ml})$ were collected and assayed for aminopeptidase activity. The fractions showing significant aminopeptidase activity were pooled and concentrated (Microcon-10 microconcentrator, Amicon) in a microcentrifuge at $15000 \mathrm{~g}$. All chromatography was performed using FPLC equipment (Pharmacia).

Electroelution was carried out on native PAGE gels to recover the aminopeptidase. Identical samples were loaded in all of the wells of a non-denaturing (native) PAGE gel. The aminopeptidase was visualized by activity staining the gel and a strip corresponding to the activity was excised from the gel. The protein within this gel matrix was electroeluted from the gel using Miniprotean II electroelution apparatus. A $10 \mathrm{kDa}$ molecular mass cut-off membrane was used to capture the protein during the electroelution step. A concentration step was carried out to reduce the volume of the sample to approximately $100 \mu \mathrm{l}$ (Microcon-10).

Native PAGE gels were subjected to electroblotting (Milliblot) to enable the aminopeptidase (in an active form) to be immobilized on an inert membrane (Immobilon-P). The electroblotting was carried out at $2 \mathrm{~mA} \mathrm{~cm}$ gel area for $30 \mathrm{~min}$. Following the blotting step, the Immobilon was stained with a 
Coomassie stain consisting of Coomassie Brilliant blue R-250 $(10 \mathrm{mg})$, methanol $(5 \mathrm{ml})$ and water $(5 \mathrm{ml})$.

Characterization of the aminopeptidase. Preparative isoelectric focusing (LKB 8101 Ampholine Electrofocusing Equipment) was carried out on samples of crude enzyme. A solution of ampholytes (Pharmacia) was used to produce a $\mathrm{pH}$ range of $\mathrm{pH} 3-10$. The electrofocusing was performed at $450 \mathrm{~V}$ for $30 \mathrm{~h}$ whilst being cooled by means of a water jacket. Fractions $(1 \mathrm{ml})$ of the electrofocused contents of the column were collected, each fraction was assayed for aminopeptidase activity and the $\mathrm{pH}$ measured.

Denaturing and non-denaturing (native) PAGE techniques (Laemmli, 1970) were utilized in characterizing and determining the purity of the aminopeptidase enzyme. Resolving gels of $7.5 \%$ acrylamide with stacking gels of $4 \%$ acrylamide were cast. Myosin (205 kDa), $\beta$-galactosidase $(116 \mathrm{kDa})$, phosphorylase $\mathrm{B}$ $(97.4 \mathrm{kDa})$, bovine albumin $(66 \mathrm{kDa})$, egg albumin $(45 \mathrm{kDa})$, glyceraldehyde-3-phosphate dehydrogenase (36 kDa), carbonic anhydrase $(29 \mathrm{kDa})$, trypsinogen $(24 \mathrm{kDa})$ and trypsin inhibitor $(20 \cdot 1 \mathrm{kDa})$ were used as molecular mass markers.

Gels were fixed and stained by one of three techniques; (i) Coomassie Brilliant blue R-250 staining, (ii) silver staining (Bio$\mathrm{Rad}$ ) according to manufacturer's instructions or (iii) activity staining. Activity staining for aminopeptidase was carried out as follows (Dr Anthony Rogers, University of Adelaide, Australia, unpublished). N-terminal leucine liberated from the tripeptide substrate Leu-Gly-Gly ( $5 \mathrm{mg} \mathrm{ml}^{-1}$ ) was oxidized by L-amino acid oxidase $\left(1 \mathrm{mg} \mathrm{ml}^{-1}\right)$ to release hydrogen peroxide. This was reacted with 0 -dianisidine dihydrochloride $\left(4 \mathrm{mg} \mathrm{ml}^{-1}\right)$ in the presence of horseradish peroxidase $\left(1 \mathrm{mg} \mathrm{ml}^{-1}\right)$ to produce a colour change. The reagents were made up in $2 \mathrm{ml}$ Tris $/ \mathrm{HCl}$ $(0 \cdot 1 \mathrm{M}, \mathrm{pH} 8.0)$. The gel was wrapped in plastic film and incubated at $37^{\circ} \mathrm{C}$. Activity was shown by a brown colouration after incubation for 4-8 h. All reagents used in the staining techniques were prepared with purified water from a system consisting of a Reverse Osmosis De-ioniser and a Still Plus 'Water Polisher' (Purite).

The substrate specificity of the aminopeptidase enzyme was investigated using LRA ZYM AP strips (bioMérieux) which allowed the simultaneous study of the 20 substrates contained in the AP-I and AP-III strips. Aliquots of aminopeptidase which had been purified by both ion exchange and gel filtration, and crude enzyme were added to the cupules on the strips. The samples were standardized by diluting to give the equivalent activity with respect to leucine $p$-nitroanilide.

Experiments were performed on the aminopeptidase using a variety of enzyme inhibitors (see Table 4) and the metal ions $\mathrm{Ca}^{2+}, \mathrm{Mg}^{2+}, \mathrm{Mn}^{2+}, \mathrm{Ba}^{2+}, \mathrm{Co}^{2+}, \mathrm{Cd}^{2+}, \mathrm{Ni}^{2+}, \mathrm{V}^{3+}$ and $\mathrm{Zn}^{2+}$. The standard aminopeptidase assay was modified and consisted of $700 \mu \mathrm{l}$ buffer, $170 \mu \mathrm{l}$ leucine $p$-nitroanilide substrate $(8 \mathrm{mM})$, $30 \mu \mathrm{l}$ enzyme and $100 \mu \mathrm{l}$ inhibitor in a $1 \mathrm{ml}$ cuvette. Two types of experiments were carried out: (i) the reaction mixture (without substrate) was incubated (room temperature $19 \pm 2{ }^{\circ} \mathrm{C}$ ) with inhibitor or metal ion salt for $30 \mathrm{~min}$, substrate was then added and the rate of reaction measured as above; (ii) the enzyme was incubated with EDTA $(1 \mathrm{mM})$ for $20 \mathrm{~min}$, a metal ion solution ( $5 \mathrm{mM}$ final concentration) was then added and the reaction mixture was incubated for a further $20 \mathrm{~min}$ before finally adding substrate and following the reaction rate as previously stated.

A sample of the aminopeptidase enzyme, eluted from a native gel, was used for the determination of the $\mathrm{N}$-terminal amino acid sequence (Immune Systems Ltd). The $\mathrm{N}$-terminal sequence was compared to other protein sequences using the following databases: Brookhaven Protein Data Bank, Swiss-Prot 26.0, PIR 38.0 (complete), CDS translations from GenBank (R) release 79.0, TDF transcription factor (protein) database release 7.0 , six-frame translations of representative human Alu repeats and Kabat sequence of proteins of immunological interest. The sequence comparisons were performed at the National Centre for Biotechnology Information (NCBI) using the BLAST network service.

\section{RESULTS}

\section{Effect of dilution rate on aminopeptidase and TLPase production}

The effect of dilution rate on the specific activity of aminopeptidase and TLPase is shown in Table 1. A steady increase occurred in aminopeptidase activity with increasing growth rates until $0.3 \mu_{\text {rel }}$ was reached, whereafter it was severely reduced. The total TLPase activity was characterized by a general decrease in activity as dilution rate increased. The relative proportion of cellbound to extracellular aminopeptidase activity was constant regardless of dilution rate, whilst for TLPase a higher proportion of extracellular activity occurred at lower dilution rates.

\section{Purification of aminopeptidase}

The aminopeptidase was purified from the culture supernatant. Although cell-bound aminopeptidase activity was higher than that of culture supernatant, the activity in the latter contained less extraneous protein than the cell lysate. The supernatant fluid contained about $0.1 \mathrm{mg}$ protein $\mathrm{ml}^{-1}$. Aliquots of the concentrated crude enzyme were applied to an ion exchange column. Fractions showing significant activity (Fig. 1) were pooled, concentrated and applied to a gel filtration column. Fractions collected were assayed for aminopeptidase activity (Fig. 2). Two major peaks of aminopeptidase activity were eluted, one between fractions 16 and 18, and the other between fractions 24 and 28 . The first peak was in the void volume of the column and therefore represents molecules with a molecular mass above $300000 \mathrm{Da}$. The second peak represents aminopeptidase activity from molecules with lower molecular masses. There was no TLPase activity associated with the peaks.

A non-ionic detergent (Triton $\mathrm{X}-100$ ) was used to investigate the possibility that the high-molecular-massassociated activity was due to aggregated enzyme molecules. If the high-molecular-mass activity was due to aggregation of enzyme, the Triton would serve to disaggregate it (Ingham et al., 1983). However, if the activity was due to a true high molecular mass form of the aminopeptidase, then it would be unaffected. The experiment was repeated equilibrating both buffer and sample with Triton X-100. The peak associated with the void volume disappeared (Fig. 2) leaving only one peak between fractions 24 and 28 . From these results, the approximate molecular mass of the aminopeptidase was shown to be $64 \mathrm{kDa}$. Subsequently, fractions showing 
Table 1. The effect of specific growth rate on biomass, total enzyme production and relative proportion of cell-bound and extracellular enzyme activity for the aminopeptidase and TLPase of $C$. gingivalis

Assays were carried out, in quadruplicate, on three consecutive samples taken from steady-state culture over a $3 \mathrm{~d}$ period. Data are the means of 12 determinations.

\begin{tabular}{|c|c|c|c|c|c|c|}
\hline \multirow[t]{2}{*}{$\mu_{\text {rel }}$} & \multirow[t]{2}{*}{$\begin{array}{c}\text { Dilution } \\
\text { rate } \\
\left(\mathbf{h}^{-1}\right)\end{array}$} & \multirow[t]{2}{*}{$\begin{array}{l}\text { Biomass } \\
\text { (mg dry } \\
\text { wt } \mathrm{ml}^{-1} \text { ) }\end{array}$} & \multicolumn{2}{|c|}{$\begin{array}{l}\text { Specific activity } \\
\text { [ } \mu \mathrm{mol} \text { product } \\
\text { formed } \mathrm{min}^{-1} \\
\text { (mg dry wt } \\
\text { cells })^{-1} \text { ] }\end{array}$} & \multicolumn{2}{|c|}{$\begin{array}{c}\text { Relative } \\
\text { proportions } \\
\text { of cell-bound/ } \\
\text { extracellular } \\
\text { activity }\end{array}$} \\
\hline & & & Apase & TLPase & Apase & TLPase \\
\hline 0.0375 & 0.0105 & $0 \cdot 3$ & 104 & $1 \cdot 6$ & $94 / 6$ & $74 / 26$ \\
\hline 0.075 & 0.021 & 0.295 & 109 & $0 \cdot 4$ & $96 / 4$ & $99 / 1$ \\
\hline $0 \cdot 15$ & 0.042 & 0.29 & 144 & 0.5 & $95 / 5$ & $100 / 0$ \\
\hline 0.3 & 0.084 & $0 \cdot 285$ & 359 & 0.7 & $95 / 5$ & $100 / 0$ \\
\hline 0.6 & $0 \cdot 168$ & $0 \cdot 24$ & 20 & 0.5 & $95 / 5$ & $100 / 0$ \\
\hline
\end{tabular}

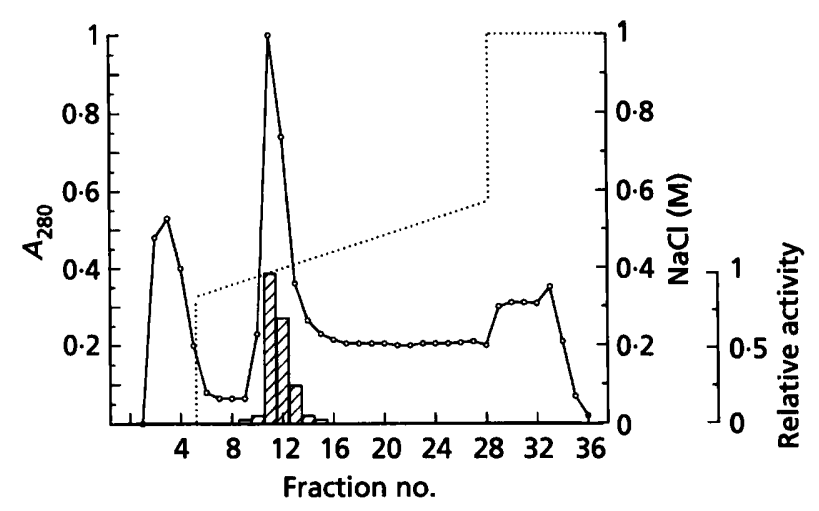

Fig. 1. Anion exchange chromatography of concentrated crude enzyme showing aminopeptidase activity in the fractions collected. $O, A_{280} ;---, \quad N a C l$ concentration; $\square$, aminopeptidase activity.

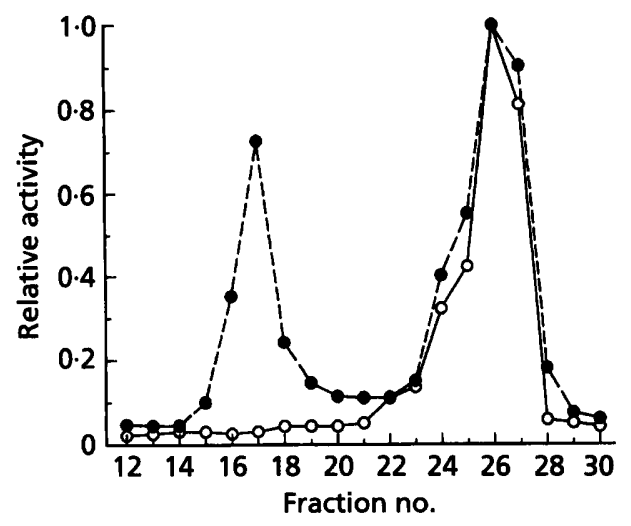

Fig. 2. Aminopeptidase activity in fractions from a gel filtration column when equilibrated with or without Triton X-100 $(0.5 \%$ $v / v)$. $O$, equilibrated with Triton $X-100 ; 0$, equilibrated without Triton X-100. activity from the ion exchange chromatography step were pooled, concentrated by ultrafiltration and dialysed against a buffer containing Triton X-100 prior to gel filtration chromatography. The purification of the aminopeptidase is summarized in Table 2. A purification factor of 113 was achieved for the enzyme derived from the culture supernatant.

\section{Properties of the aminopeptidase}

pH optimum for catalytic activity. The $\mathrm{pH}$ optimum for catalytic activity for both the aminopeptidase and the TLPase was shown to be $\mathrm{pH} 7 \cdot 5$.

pl and molecular mass. The $\mathrm{pI}$ of the aminopeptidase was shown to be $\mathrm{pH} 6 \cdot 3$. Samples of enzyme which had undergone ion exchange chromatography and gel filtration chromatography were concentrated by ultrafiltration and subjected to native PAGE and subsequently stained for protein, using Coomassie blue, or for aminopeptidase activity. The activity-stained band corresponded to the major Coomassie-blue-stained band. The band containing the enzyme was excised and subjected to SDS-PAGE. One band was detected by silver staining, thus confirming the purity of this preparation. Using molecular mass markers, the mass of the aminopeptidase was calculated to be $61 \mathrm{kDa}$.

Substrate specificity. The specificity of the aminopeptidase towards $\beta$-naphthylamide derivatives of 20 amino acids was investigated (Table 3 ). The partially purified aminopeptidase (after ion exchange and gel filtration) hydrolysed all of the derivatives with a free $\mathrm{N}$-terminal amino acid, but not the two benzyloxycarbonyl-blocked derivatives.

Effects of inhibitors and metal ions on aminopeptidase activity. The enzyme activity was inhibited by chelating 
Table 2. Purification of $C$. gingivalis aminopeptidase

Results are the means of three experiments.

\begin{tabular}{|c|c|c|c|c|c|c|}
\hline Fraction & $\begin{array}{l}\text { Volume } \\
\text { (ml) }\end{array}$ & $\begin{array}{c}\text { Total } \\
\text { activity } \\
(\mu \mathrm{mol} \\
\text { product } \\
\text { formed } \\
\left.\text { min }^{-1}\right)\end{array}$ & $\begin{array}{c}\text { Total } \\
\text { protein } \\
(\mathrm{mg})\end{array}$ & $\begin{array}{c}\text { Specific } \\
\text { activity } \\
\text { [ } \mu \mathrm{mol} \\
\text { product } \\
\text { formed } \\
\min ^{-1}(\mathrm{mg} \\
\text { protein }^{-1} \text { ] }\end{array}$ & $\begin{array}{l}\text { Purification } \\
\text { factor }\end{array}$ & $\begin{array}{c}\text { Yield } \\
(\%)\end{array}$ \\
\hline Crude culture supernatant & 5000 & 458 & 450 & 60 & 1 & 100 \\
\hline Ultrafiltration & 50 & 356 & $142 \cdot 5$ & 150 & $2 \cdot 5$ & 78 \\
\hline Ion exchange* & 2 & 90 & $10 \cdot 8$ & 500 & $8 \cdot 2$ & 19 \\
\hline Gel filtration* & 0.5 & 30 & 0.43 & 4200 & 69 & 7 \\
\hline Electroelution $\dagger$ & $0 \cdot 4$ & 16 & $0 \cdot 14$ & 6800 & 113 & $3 \cdot 4$ \\
\hline
\end{tabular}

* Relevant fractions were concentrated by ultrafiltration.

† Sample concentrated by ultrafiltration.

Table 3. Hydrolysis of $\beta$-naphthylamide derivatives of 20 amino acids (AP-I and AP-III strips) by crude enzyme concentrate and purified aminopeptidase

Data represent the API score after a $3 \mathrm{~h}$ incubation period, and are approximate being equivalent to $\mathrm{nmol} \boldsymbol{\beta}$-naphthylamine liberated. The experiment was repeated twice and the results were confirmed. $N-\mathrm{CB} 2$, benzyloxycarbonyl group.

\begin{tabular}{|lll|}
\hline $\begin{array}{l}\boldsymbol{\beta} \text {-Naphthylamide } \\
\text { substrate }\end{array}$ & $\begin{array}{c}\text { Crude } \\
\text { enzyme }\end{array}$ & $\begin{array}{c}\text { Purified } \\
\text { aminopeptidase }\end{array}$ \\
\hline (a) AP-I & & \\
L-Tyrosyl- & 1 & 1 \\
L-Pyrrolidonyl- & 1 & 1 \\
L-Phenylalanyl- & 2 & 3 \\
L-Lysyl- & 2 & 2 \\
L-Hydroxyprolyl- & $0 \cdot 5$ & 4 \\
L-Histidyl- & 2 & 2 \\
Glycyl- & 2 & 4 \\
L-Aspartyl- & $2 \cdot 5$ & 3 \\
L-Arginyl- & $2 \cdot 5$ & 2 \\
L-Alanyl- & 2 & 2 \\
(b) AP-III & & \\
N-CBZ-L-argininyl-4-methoxy- & 1 & 0 \\
L-Glutaminyl- & $2 \cdot 5$ & $2 \cdot 5$ \\
$\alpha$-L-Glutamyl- & $2 \cdot 5$ & 5 \\
L-Isoleucyl- & 1 & 1 \\
L-Ornithyl- & 5 & $2 \cdot 5$ \\
L-Prolyl- & 3 & 2 \\
L-Seryl- & 5 & 2 \\
L-Threonyl- & 2 & 2 \\
L-Tryptophyl- & $2 \cdot 5$ & $3 \cdot 5$ \\
N-CBZ-glycyl-glycyl-L-arginyl & 1 & 0 \\
\hline & & \\
\hline
\end{tabular}

agents (Table 4) with $100 \mathrm{mM}$ EDTA giving a $50 \%$ reduction in activity. Heavy metal ions $\left(\mathrm{Co}^{2+}, \mathrm{Cd}^{2+}, \mathrm{Ni}^{2+}\right.$ and $\left.\mathrm{Zn}^{2+}\right)$ showed a greater than $90 \%$ inhibition of
Table 4. Effect of pre-incubation with various enzyme inhibitors on the activity of aminopeptidase

The residual activity shown is the amount of activity retained after a $30 \mathrm{~min}$ incubation at room temperature with the inhibitor. All assays were carried out in triplicate and the mean values are shown.

\begin{tabular}{|lccc|}
\hline Inhibitor & $\begin{array}{c}\text { Final } \\
\text { concentration } \\
\text { (mM) }\end{array}$ & $\begin{array}{c}\text { Residual Percentage } \\
\text { activity } \\
(\%)\end{array}$ & $\begin{array}{c}\text { inhibition } \\
\text { (m) }\end{array}$ \\
\hline Control & - & 100 & 0 \\
EDTA & 10 & 21 & 79 \\
1,10-Phenanthroline & 1 & 14 & 86 \\
PHMB & 10 & 34 & 66 \\
Iodoacetamide (IAA) & 10 & 92 & 8 \\
AEBSF & 1 & 100 & 0 \\
Bestatin & 10 & 100 & 0 \\
\hline
\end{tabular}

activity. EDTA-inactivated enzyme activity could be reactivated 38 and $22 \%$, respectively, by $\mathrm{Mg}^{2+}$ or $\mathrm{Ca}^{2+}$ ions.

\section{$\mathbf{N}$-terminal sequence of the aminopeptidase}

The sequence data were limited to the first 10 amino acids which were determined to be Asp-Val-Asn-Met-Leu-TrpTyr-Val-x-Arg.... The sequence of 10 amino acids has an unidentified residue ( $x$ in the above sequence), possibly due to masking by high background levels of other residues. No N-terminal sequence homology could be identified by reference to databases (see Methods) and consequently no match with any other aminopeptidases was found. 


\section{DISCUSSION}

A continuous culture system was used to study the production of aminopeptidase and TLPase enzymes. It has been reported that $C$. gingivalis cells produce various enzymes when grown in batch culture (Nakamura \& Slots, 1982; Slots, 1982) but the extent to which the activities were cell-bound or extracellular remained unstudied. Since the chemostat is the only way of controlling growth rate, it was used in an early experiment to study the effects of growth rate on the production and export of hydrolytic enzymes. The results show two different trends between growth rate and hydrolytic enzyme production. The aminopeptidase specific activity peaked at $0 \cdot 3 \mu_{\text {rel }}$ and showed a constant ratio of cell-bound to extracellular activity. However, the TLPase specific activity increased with decreasing growth rate and clearly showed that the ratio of cell-bound enzyme to extracellular enzyme decreases with decreasing relative growth rate. This finding is consistent with results for TLPase of Porphyromonas gingivalis where the ratio of cell-bound to extracellular activity decreases with decreasing growth rate (Minhas \& Greenman, 1989).

The $\mathrm{pH}$ optimum for catalytic activity of both the aminopeptidase and TLPase was $\mathrm{pH} 7 \cdot 5$. This suggests that, if the enzymes are produced in vivo, they would be active against their natural substrates in the periodontal tissues since the $\mathrm{pH}$ of subgingival plaque and the periodontal pocket is in the range $\mathrm{pH} 7 \cdot 0-8 \cdot 0$ (Bickel \& Cimasoni, 1986).

The molecular masses of aminopeptidases characterized from various sources in nature extend over a wide range, from $390 \mathrm{kDa}$ (Cueva et al., 1989) to $29 \mathrm{kDa}$ (Ben-Basset et al., 1987). The aminopeptidase of $C$. gingivalis had an estimated molecular mass of $61 \mathrm{kDa}$ (SDS-PAGE) or $64 \mathrm{kDa}$ (gel filtration) which corresponds closely with other Gram-negative aminopeptidases such as the periplasmic prolyl aminopeptidase (ca. $65 \mathrm{kDa}$ ) isolated from Acinetobacter calcoaceticus and Pseudomonas aeruginosa (Fricke \& Aurich, 1993).

The aminopeptidases produced by various strains of Capnocytophaga show wide substrate specificities (Nakamura \& Slots, 1982). In this study, comparison of the substrate specificities of the crude and purified aminopeptidase showed that the purified enzyme was capable of hydrolysing all of the substrates with free $\mathrm{N}$ terminal amino acid residues, but not the $\mathrm{N}$-terminal blocked ones. In contrast the crude enzyme preparation hydrolysed all the substrates, including the $\mathrm{N}$-terminal blocked ones, implying that other enzymes were present. It is possible that TLPase, which can hydrolyse Nterminal blocked amino acid substrates (Shibata et al., 1992), was present in small amounts in the crude enzyme preparation. The partially purified aminopeptidase was purified by both cation exchange and gel filtration chromatography. A silver-stained native PAGE gel of purified aminopeptidase showed one main band, which was attributed to the aminopeptidase (by activity staining) and three other faint unidentified bands. The main band was aminopeptidase and had been selected for throughout the purification procedure by assays using L-leucine $p$ nitroanilide and the tripeptide Leu-Gly-Gly (activity stain) as substrates.

Circumstantial evidence suggests that $C$. gingivalis produces only a single aminopeptidase since: (i) the activity profile with four substrates on all fractions from gel filtration chromatography were similar (Spratt, 1994); and (ii) the substrate specificity of the purified aminopeptidase, as tested against 20 substrates, was shown to be wide and similar to that of the crude enzyme (Table 3).

The action of various inhibitors on the aminopeptidase activity indicated that it should be classed as a metalloprotease or a metal-activated protease. It can be deduced from the results that the aminopeptidase was not a cysteine or a serine protease since the action of IAA, a cysteine protease inhibitor, and 4-(2-aminoethyl)benzenesulfonyl fluoride (AEBSF), a serine protease inhibitor, was negligible. The effect of chelating agents (EDTA and 1,10phenanthroline) and metal ions identified the enzyme as a metallo-protease or a metal-activated protease with a requirement for $\mathrm{Mg}^{2+}$ or $\mathrm{Ca}^{2+}$. The effect of $p$-hydroxymercuribenzoate (PHMB) indicated a requirement for free sulphydryl groups for normal catalytic function of the aminopeptidase. Bestatin insensitivity indicates that the aminopeptidase of $C$. gingivalis is structurally different to the mammalian-derived aminopeptidase $M$ (Umezawa, 1982) and aminopeptidase N (Kumano \& Sugawara, 1992), both of which are inhibited by bestatin.

The aminopeptidase is produced in substantial amounts by $C$. gingivalis suggesting an important role in the cells natural habitat. Other oral bacteria, for example Streptococcus mitis (Andersson et al., 1992) and Treponema vincentii (Mäkinen et al., 1988) also produce aminopeptidases and, together or separately, these enzymes could provide a steady supply of amino acids to the consortium of organisms in the mouth by the stepwise hydrolysis of proteins or peptides. The TLPases of $C$. gingivalis and Porphyromonas gingivalis, which are endopeptidases, may ensure that proteins or large peptides are degraded to give an increase in the oligopeptides available for aminopeptidase action. Assuming that the enzymes can work in concert, we can envisage co-operation and competition between members of the oral consortium for the production and use of free amino acids.

\section{REFERENCES}

Andersson, C., Linder, L. E., Sund, M. \& Lönnies, H. (1992). Purification and characterization of an aminopeptidase from Streptococcus mitis ATCC 903. Curr Microbiol 25, 261-267.

Ando, K. (1980). Collagenase, dipeptidylpeptidase IV and cathepsin $\mathrm{D}$ activities in gingival fluid and whole saliva from patients with periodontal disease. Jap J Periodont 22, 387-402.

Ben-Basset, A., Bauer, K., Sheng-Yung, C., Myambo, C., Boosman, A. \& Chang, S. (1987). Processing of the initiation methionine from proteins: properties of the Escherichia coli methionine aminopeptidase and its gene structure. J Bacteriol 169, 751-757.

Bickel, M. \& Cimasoni, G. (1986). Recent advances in gingival crevicular fluid research. In The Borderland Between Caries and 
Periodontal Disease III. Edited by T. Lehner \& G. Cimisoni. Geneva: Médecine et Hygiene.

Bradford, M. M. (1976). A rapid and sensitive method for the quantitation of microgram quantities of protein utilizing the principle of protein-dye binding. Anal Biochem 72, 248-254.

Cueva, R., Garcia-Alvarez, N. \& Suárez-Rendueles, P. (1989). Yeast vacuolar aminopeptidase yscI. Isolation and regulation of the APE1 (LAP4) structural gene. FEBS Lett 259, 125-129.

D'Amato, R. F., Eriquez, L. A., Tomfohrde, K. M. \& Singerman, E. (1978). Rapid identification of Neisseria gonorrboeae and Neisseria meningitidis by using enzymatic profiles. J Clin Microbiol 7, 77-81.

Fricke, B. \& Aurich, H. (1993). Periplasmic aminopeptidases in Acinetobacter calcoaceticus and Pseudomonas aeruginosa. J Basic Microbiol 33, 291-299.

Green, S. S., Goldberg, H. S. \& Blenden, D. C. (1967). Enzyme patterns in the study of Leptospira. Appl Microbiol 15, 1104-1113.

Greenman, J., Holland, K. T. \& Cunliffe, W. J. (1981). Effects of glucose concentration on biomass, maximum specific growth rate and extracellular enzyme production by three species of cutaneous Propionibacteria grown in continuous culture. J Gen Microbiol 127, 371-376.

Holdeman, L. V., Moore, W. E., Cato, E. P., Burmeister, J. A., Palcanis, K. G. \& Ranney, R. R. (1985). Distribution of Capnocytophaga in periodontal microfloras. $J$ Periodont Res 20, 475-483.

Holland, K. T., Greenman, J. \& Cunliffe, W. J. (1979). Growth of Propionibacteria on synthetic medium: growth yields and exoenzyme production. J Appl Bact 47, 383-394.

Hopsu-Havu, V. K., Măkinen, K. K. \& Glenner, G. G. (1966). Purification of a mammalian peptidase selective for $\mathrm{N}$-terminal arginine and lysine residues: aminopeptidase B. Arch Biochem Biopbys 114, 557-566.

Ingham, E., Holland, K. T., Gowland, G. \& Cunliffe, W. J. (1983). Studies of the extracellular proteolytic activity produced by Propionibacterium acnes. J Appl Bact 54, 263-271.

Irving, J. T., Socransky, S. S. \& Tanner, A. C. R. (1978). Histological changes in experimental periodontal disease in rats mono-infected with Gram-negative organisms. J Periodont Res 13, 326-332.

Kumano, N. \& Sugawara, S. (1992). Ubenimex (Bestatin), an aminopeptidase inhibitor, modulates protein kinase $\mathrm{C}$ in $\mathrm{K} 562$ cells. $J$ Biol Regulat Homeostat Agents 6, 116-120.

Laemmli, U. K. (1970). Cleavage of structural proteins during the assembly of the head of bacteriophage T4. Nature 227, 680-685.
Leadbetter, E. R., Holt, S. C. \& Socransky, S. S. (1979). Capnocytophaga: new genus of Gram-negative gliding bacteria. I. General characteristics, taxonomic considerations and significance. Arch Microbiol 122, 9-16.

Măkinen, K. K., Syed, S. A., Loesche, W. J. \& Măkinen, P.-L. (1988). Proteolytic profile of Treponema vincentii ATCC 35580 with special reference to collagenolytic and arginine aminopeptidase activity. Oral Microbiol Immunol 3, 121-128.

Marsh, P. D., Hunter, J. R., Bowden, G. H., Hamilton, I. R., McKee, A. S., Hardie, J. M. \& Ellwood, D. C. (1983). The influence of growth rate and nutrient limitation on the microbial composition and biochemical properties of a mixed culture of oral bacteria grown in a chemostat. $J$ Gen Microbiol 129, 755-770.

Mashimo, P. A., Yamamoto, Y., Slots, J., Park, B. H. \& Genco, R. J. (1983). The periodontal microflora of juvenile diabetics: culture, immunofluorescence and serum antibody studies. $J$ Periodontol 54, 420-430.

Minhas, T. \& Greenman, J. (1989). Production of cell-bound and vesicle-associated trypsin-like protease, alkaline phosphatase and $N$-acetyl- $\beta$-glucosaminidase by Bacteroides gingivalis strain W50. $J$ Gen Microbiol 135, 557-564.

Nakamura, M. \& Slots, J. (1982). Aminopeptidase activity of Capnocytophaga. J Periodont Res 17, 597-603.

Newman, M. G., Socransky, S. S., Savitt, E. D. \& Crawford, A. (1976). Studies in the microbiology of periodontosis. J Periodontol 47, 373-379.

Shibata, Y., Fujimura, S. \& Nakamura, T. (1992). Isolation and characterization of enzymes hydrolyzing chymotrypsin synthetic substrate (enzyme 1) and trypsin synthetic substrate (enzyme 2) from the envelope fraction of Capnocytophaga gingivalis. Med Microbiol Immunol 181, 107-115.

Slots, J. (1976). The predominant cultivable organisms in juvenile periodontitis. Scand J Dent Res 84, 1-10.

Slots, J. (1982). Importance of black-pigmented Bacteroides in human periodontal disease. Etiol Microb Spec 2, $27-45$.

Spratt, D. A. (1994). A study of aminopeptidase and other bydrolytic enzymes produced by Capnocytophaga gingivalis. $\mathrm{PhD}$ Thesis, University of the West of England, Bristol, UK.

Tempest, D. W. (1970). The continuous cultivation of microorganisms. I. Theory of the chemostat. Metbods Microbiol 2, 259-276.

Umezawa, H. (1982). Low molecular weight enzyme inhibitors of microbial origin. Annu Rev Microbiol 36, 75-99.

Received 29 June 1995; revised 31 July 1995; accepted 8 August 1995. 